\title{
Motivation and Employee Effectiveness in Online Learning Environments: Leadership Strategies of New Generation and Emotional Intellect
}

\author{
https://doi.org/10.3991/ijet.v15i09.13921 \\ Nail Israfilov \\ University associated with Inter-Parliamentary Assembly of Eurasian Economic Community, \\ St. Petersburg, Russia \\ Oksana Borisova \\ Financial University under the Government of the Russian Federation, Moscow, Russia \\ Oxana Kartashova \\ Sechenov First Moscow State Medical University (Sechenov University), Moscow, Russia \\ Nataliia Davydova ${ }^{(\bowtie)}$ \\ Russian State Vocational Pedagogical University, Yekaterinburg, Russia \\ nataliia.davydova.86@bk.ru \\ Galia Biserova \\ Elabuga Institute (branch) of Kazan (Volga Region) Federal University, Elabuga, Russia
}

Aleksandr Gryaznukhin

Siberian Federal University, Krasnoyarsk, Russia

\begin{abstract}
The article aims at analyzing the impact of leadership technologies and emotional intellect within the motivation systems in educational organizations in the EU and CIS countries on employee effectiveness in online learning environments. During research implementation, it has been also identified the direct relationship between these technologies and profitability of these organizations. The research has shown that the issue of effective motivation and incentive system which would ensure a real professional development for the employees of educational organizations and makes the organization a leading one is of rather in-depth conceptual character and needs development of an adequate employee strategy by using more contemporary methods of influencing them. The achieved results are unique and can be used within the study of the issues related to online learning and motivation as of employees of educational organizations, so as employees in overall in their professional activity.
\end{abstract}

Keywords — online environments, educational organizations, leadership, emotional intellect, motivation effectiveness. 


\section{Introduction}

The digital century requires a constant modernization of the state service as well as in education. The best solution is an on-going training of state employees according to the latest educational tendencies and technologies. These changes need new skills and, extremely important, new approaches in work. The most modern concepts in state education management used in developed world economies are NPM (New Public Management), Good governance (GG), Government On-Line (GOL) etc. One of the key underlying components of these concepts is leadership and capability to manage emotions as of employees as of students, however not in a traditional context. Such an assumption is determined by absolutely new understanding of the way of life and conditions in which young generation can work as they are grown up in online environment and information technologies - " $\mathrm{X}$ ", "Y" and " $\mathrm{Z}$ ". For the generation the traditional motivation and incentive methods are not already relevant and ineffective in practice. Moreover, such changes influence the employee turnover, then the image of the organization (that is rather important for educational institutions, for example, for universities under enrollment of applicants) and its financial results eventually.

\subsection{Public service education opportunities}

Following forecasts of certain analysts as regards the changes related to the public management education system it is worth to state that in the nearest future organizations will become more "human" by focusing on people as an essential competitive benefit. They will create conditions, which allow their employees, pupils, students, and organizations specialized in advanced training to apply unique personal traits in the work emotional intellect, creativity, innovation etc. Thus, the public sector should keep up with the business. It is necessary to create an attractive image of the public service as an employment place for school leavers, and educational institutions should teach and educate future leaders for whom there should be comfortable conditions for development of their leadership capabilities [1-4].

Most research results focused on up-to-date tendencies in education as in public organizations [5-8]. They demonstrate that it is more reasonable to refocus from bureaucratic approach towards the organization of the working process in public sector as in educational institutions, so as in public education management authorities at local and central levels up to more innovative, decentralized ones, ensure the right for young leaders to take decisions independently and bear responsibility for their fulfillment. In the future, there will be no critical need in "regular employees" as all regular work has been gradually automatized. The future is defined by new powerful values among which the creativity and innovation - personal qualities that are not correlated with algorithmic thinking of computers [9-12].

As of now, recruiters should, including the educational sector, search for not common executives but people competencies of whom in future during their professional development can prevail competencies of not only their managers, but also those who are currently leaders. 
At the same time for disclosing capacities of the specialist, the definite conditions are necessary. Among significant ones are high mission and awareness of its engagement to it. So, the mission of state management does not already refer to the establishment of institutions and infrastructure of social development, which in such a way defines the future, but insurance of domestic cohesion that is cooperation and collective actions towards general direction of different powers (social, national, intellectual) which exist in the society $[13,14]$.

The public service should refer to the harmonization of interests of business and citizens that is a primary factor for increasing national competitiveness and safety of any country. Leadership is exactly the tool that helps to implement it. In order that the stated goals become true, the public service should have so necessary characteristics such as flexibility and adaptability. It enables to transfer from strict hierarchies to decentralization that is allowing departments and separate employees to acquire more freedom in their activities. As a result, there is leadership [15].

\subsection{The key trends analysis}

Among key trends, which define the future, it is worth to emphasize technologies, demography and geopolitics. Thus, state authorities pay a great attention to the geopolitics to control integration processes - merging, acquisition and formation of new assets by international corporations (holding companies and groups) in various regions of the world. The demography refers to the changes in the employee structure, appearing of new generation, their capabilities and energy of which are necessary to direct properly and educate respect to the nation, state. Regarding technologies it is necessary to carry out more sophisticated process automation in public services related to document turnover, accounting, information storage (for instance, by the help of cloud-technologies) and in future - robotization of main operational processes [16,17].

Therefore, it is essential to think about what strategies in state education management are to be elaborated, how system/methods/tools of motivation and incentive can be improved in conformity with other needs of young generation that is the state could survive within up-to-date changes. Thus, we should consider the entire labor ecosystem, identify and train the employees who have respective future skills, manage the employee attraction and satisfaction. These objectives are under competence of not only employee services, which mainly perform document turnover, but under competence of the whole employee management $[18,19]$.

Among key trends of professional development in the framework of education improvement, it is necessary to review the operation of employee services in the composition of executive and administrative units within state education management. Modern employee requirements will require fundamental changes in the methodology of employee management. This requires finding, retaining and training the employees who will acquire respective skills for future. The employee services should function properly in the composition of public service, be capable to plan its employee needs, search for and select candidates, ensure employees' adaptation and assess their effectiveness in online learning environments, form a corporate culture and a positive moral and psychological atmosphere in the team. Compared to the corporate sector, the public 
service has not yet made the transition from "treating the documents" to "working with people" (HR). In this regard, together with the authorized body in the educational field, it is necessary to envisage the training of specialists in employees' management. Moreover, it refers to the strengthening the importance of HR in the development of leaders. HR must fulfill the functions of the consultant and organize the activity in line with organization's needs by using data analysis and forecasting methods for the future. Only $17 \%$ of interviewed employees in the framework of the Global Leadership Forecast 2018 study are deserved to be attracted $[1,2,20]$. Employees need to have analytical skills and digital knowledge, be prepared for challenges and responsible for the preparation and development of leaders.

\subsection{Influence on public relations}

In addition, it is important to update the regulatory framework in education; its further development is one of the main tasks as for now. Governing of legal relations in education is the basis of the state's influence on public relations in education and should ensure that the interests of involved parties to values are taken into account. The Federal Law N 273-FZ on Education in the Russian Federation of 12/29/2012 (amended on $06 / 03 / 2019$ ) states the right of every citizen for qualitative education, equal rights upon establishing educational institutions and education financing, of relevant conditions for teaching children, including children with disabilities, enhancing social and non-financial protection of teachers, modernization of education management. The current system of encouragement and bonus payment of employees involved in education, salary financing procedure of vocational training, work experience for orphans and children deprived of parental care during their training in vocational schools, conditions for enrollment into educational institutions and financing of the educational process, which will ensure state guarantees for achieving the necessary level of education.

To meet the challenges in modern education, it is necessary to think about the context of the requirements as regards the education in new economic, social, globalization conditions. From this perspective, crucial changes in education should take place.

The research objectives are:

- compare traditional and more contemporary methods of motivation and incentive influence on the effectiveness of employees' performance in online learning environments;

- elaborate the grounds for creating new HR-strategies in online education based on leadership and emotional intellect;

- analyze the outcomes of implementation of the latest innovations and changes in public educational services activity and institutions in the EU and CIS countries;

- estimate the impact of leadership and tools on the financial performance of educational institutions, and identify how the obtained data will be assessed in numbers, based on statistical and analytical information specified in the Global Leadership Forecast 2018 report; 
Paper-Motivation and Employee Effectiveness in Online Learning Environments: Leadership ...

- evaluate whether leaders of modern generation are ready for key challenges and new responsibilities in a professional activity of an employee of educational organizations;

- propose online tools in the educational training processes of civil employees and assess whether they suit the expectations of highly potential candidates of young generation;

- elaborate the mechanism of formation and development of the leadership in state education management.

\section{$2 \quad$ Materials and Methods}

\subsection{Research Design}

Let us analyze the content and framework of the main state strategies, programs and doctrines in online education, developed and implemented by the EU and CIS countries for the last few years.

Based on the strategic importance of education development in both Europe and the CIS countries, national doctrines, programs and strategies of education development are of great significance for regulatory support of state education administration in each of these regions. Thus, in line with primary objectives of state educational programs for last years, education management should be aimed at organizing and ensuring optimal conditions for education development, establishment of its systematic self-regulation on the national, regional, local levels and in educational institutions as well as in scientific facilities [21-23].

The state policy is focused mainly on education development to determine conditions for professional growth and creative self-realization of each citizen, to cultivate a high-performance generation, to cherish and to enhance values of national culture and civil society, to develop and to strengthen an independent, democratic, social and legal state as an integral part of national and global community [21-23].

Such issues as salaries, financial and non-financial incentives, compensations, benefits and motivation for work deserve a special attention. Considering the very low level of remuneration of employees of educational institutions - school teachers, university professors, additional staff in the CIS countries compared to the European countries, non-financial motivation is, certainly, very important. In this regard, a flexible system of vacations and bonuses, working schedule are to be made up; undoubtedly, the minimum wage of teachers is to be revised. Therefore, it is worth pointing out an odd imbalance in the ratio of salaries of school teachers and university staff, caused by reforms in education for last years. Considering norms and range of wages determined by government authorities as well as additional remuneration payments at the expense of local budgets, a secondary school teacher with qualification may get much higher salary than, for example, a young employee of higher educational institution who has academic degree, scientific achievements, publications, and knows foreign languages.

European best practice has shown good results in the implementation of labor remuneration systems and material incentives based on the competence approach. The 
teacher with higher qualifications irrespective of the level of accreditation of an educational institution (school, technical school/college or university) and with more developed competencies and professional skills, can receive higher wages than his/her "less competent" colleague. Special independent commissions assess the competence and professionalism, which issue appropriate certificates to employees who have passed accreditation. Moreover, in pursuance with this approach, extra material remuneration can be obtained as a result of cooperation with pupils or students within social or research projects on which the teacher spends an additional time, but which can contribute the society. Not all young teachers will agree to work in regions, in the countryside as certain excessive payments must also be done, stimulating factors have been thought about.

Non-material motivation within competence-based approach is mainly grounded on its combination with the acmeological approach that is the personal and spiritual development of an employee in educational field. It is deemed that a person with the right set of values, life principles and confidence in future, a modern person who understands and wishes to change the future of his country for the best will make maximum efforts for it in the course of his/her work and work efficiently.

The analysis results of a number of salaries, incentives and bonuses systems in American secondary schools and, in particular, higher educational institutions are completely different. These systems include retirement plans, paid training, holidays, vacation, medical care, vision insurance, dental insurance and other services. Costs' coverage extends to as employees as their family members by the help of various insurance companies. The State Fund covers the majority of insurance installments, so employees should pay only partially. Some plans require from the employees a payment of deductible franchise in addition to their share of the premium. Long-term care insurance ensures the coverage for expenses that may be caused due to chronic illness, weakness, old age or a serious accident. The care can be rendered at home, in a care facility or in a nursing home. Moreover, it is foreseen personal vacations, financial assistance due to adoption, death of loved persons. The coaching leave is of special attention. In order to encourage employees to help today young people, the State Fund provides paid mentoring leave for participating employees. For each hour of employee's participation in mentoring activity through a qualified organization, the State Fund compares the hour of paid leave for future mentoring assignments. Employees can receive up to 40 hours of paid mentoring leave for a calendar year. Extra programs have been elaborated for the accumulation of pension savings. For the employees of higher educational institutions with a scientific degree and academic status, outstanding scientific achievements there is a specific pension system, which stipulates respective surcharges. Thus, all stated above is crucially different from the situation in the CIS countries [24-27].

Undoubtedly, we should not forget to reconsider the systems of motivation and encouragement of state employees who deal with issues related to education management in the country. So, the activity of educational institutions depends on the efficient performance of their work as a whole.

Therefore, main objectives of elaborating an education development strategy are as follows: 
- rapid and continuous feature of education modernization, increase of flexibility in responding to all processes taken place in the country and the world;

- updating the objectives and content of the education based on the implementation of a competence-based approach (experience of the European countries: Poland, Finland, the Czech Republic, etc.) and personal orientation, taking into account world best practices and principles of sustainable development;

- review of the current inefficient motivation and reward systems of the employees involved in education (both teachers and public employees); low wages;

- meeting the cultural and educational needs of national minorities, improving conditions for learning foreign languages;

- development of an effective system of national education based on universal human, multicultural, civil values;

- ensuring a systematic improvement of the quality of education on an innovative basis, modern psychological and pedagogical as well as scientific and methodological support of the educational process, etc.

\subsection{Data Analysis}

For the last time, there are more and more up-to-date concepts of motivation and inventive based on online technologies and emotional intellect. This is stipulated by the fact that organizations strive to become leaders in view of constant changes. This in turn can be achieved if there will be leaders who would motivate and inspire the employees to work being as an example and adhering to their goals. Leaders very often select ambitious and already motivated employees for their teams. These employees correspond or can correspond to indicated high requirements in future. In this case, power and coercion within this model are replaced by inducement and inspiration. As a result, based on leadership approaches the followers have behaved unusually, who steadily achieve results that are much higher than average ones. On applying leadership approach, the impact is based on the acceptance by people of the leader's requirements without the explicit or direct manifestation of power. The leader's ability to influence people enables him /her to use the power and authority gained from his followers. The behavior of leaders is the most significant factor that determines how employees will feel and work in a team. Good leaders inspire employees with enthusiasm, attract them to work and motivate them to make extra efforts to contribute the activity of the company. For educational organizations, the transition to a leadership model now is of high priority, bearing in mind the need of a better education of most people, especially young generation, the so-called "educational trend", "fashion" of education. To a certain extent, it explains the emergence of a large number of private companies. They offer educational services on the basis of trainings, master classes, workshops (short-term teaching methods), remote study, "on-line" training, which are rarely used by public educational institutions that are competitors for the latter ones in terms of attracting applicants. From our perspective, only an educational institution with a proper reputation, introducing modern technologies of education and having full-time employeesleaders, can attract the largest number of students, including paid and free of charge 
education, which certainly will directly affect the efficiency of their performance and financial results.

Taking into account the assumptions above, we should note that the leadership is revealed more effectively in a professional activity if a person at the same time occupies a managerial position. It creates a certain basis for applying both, possibly, inborn leadership qualities and personal traits (acmeological approach), as well as acquired leadership competencies in the process of study and past experience in performing duties and assignments (competence approach). Thus, the effectiveness of the use of leadership technology at managerial positions within the systems of motivation and rewards of educational organizations, from our point of view, is presented in the following functions.

- Leadership is a source of incentive and motivation. For a leader-manager is important to create a flexible and, at the same time, an effective motivation system. It is necessary to make the motivation adequate and predictable for all employees, both positive and negative. Besides, it is desirable to use a variety of incentives, apart from the standard material motivation. Sometimes money considered as the most favorable means for employees' motivation, has no desired effect, and the manager needs to look for other, more effective ways. Possible promotion, contests held in the office, verbal encouragement, the possibility of study and much more may be considered as motivation.

- Leadership is a model and way of life for employees. Employees, quite often, following their leader-manager, adapting to him/her in his/her views and work style. His/her attitude towards the work and organization should be the same as what he/she expects from his /her subordinates. An active and goal-oriented leader-manager does not only set an example, but encourage his/her employees, or (if it is not motivated subordinates) at least monitors their involvement in the work process.

Due to slightly contradictory approaches as for quantitative assessment of leadership impact on the efficiency of educational organizations' activity in the course of the research it was decided to use the statistics.

Thus, according to the research data upon more than 2500 companies from various sectors and countries, including Europe and the CIS, the results of which are reflected in the analytical report "Global Leadership Forecast: 25 Research Insights to Fuel Your People Strategy". The research was conducted jointly with companies EY (Ernst \& Young) and DDI (Development Dimensions International) in 2018. Among all surveyed organizations performing their activities in educational area, percentage of leaders, whose overall quality of educational organization's leadership is high in 2017 has made up $42 \%$ that is higher by $2 \%$ compared to the similar performance in 2014 and 2011. In turn, percentage of HR professionals whose overall quality of educational organization's leadership is high in $2017-30 \%$ that is higher by $5 \%$ compared to the similar performance 2014 and 2011 (the figure below). 


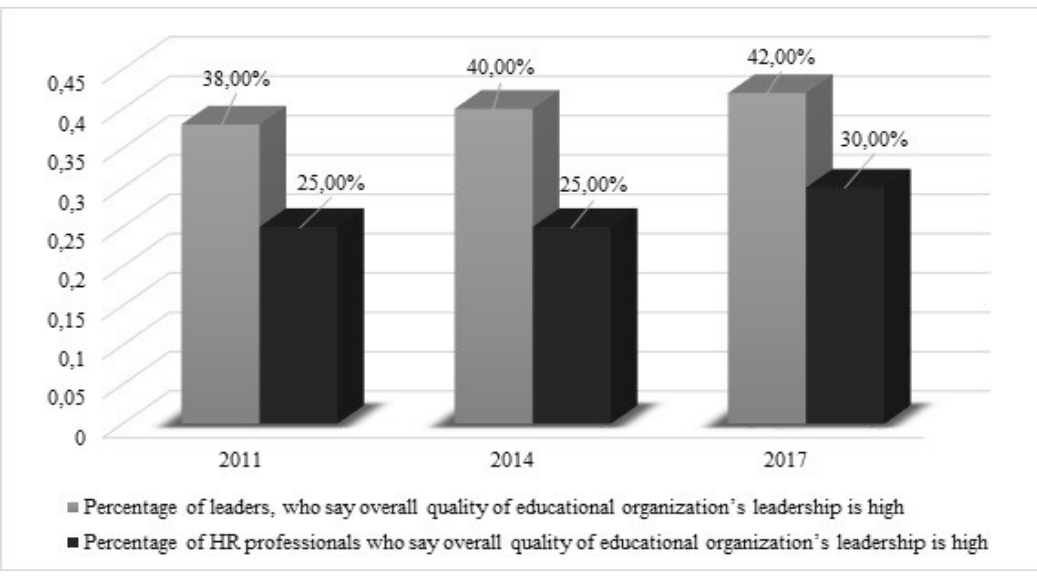

Fig. 1. Dynamics of feedback of respondent companies that consider the application of leadership model with reference to motivation systems of employee management in educational organizations as efficient, 2011-2017 (source: developed by authors based on $\mathrm{EY}, \mathrm{DDI})$.

Focusing on the data in the table below, we see that the area Education takes the second place after the Automotive industry pursuant to surveyed respondent companies in 2017. Moreover, respondents think that over time leadership technologies will be developed and applied in education rapidly (the third position in the ranking).

Table 1. Survey results of respondent companies as for application of leadership technologies in online learning environments now and in future in various world regions and industries

\begin{tabular}{|l|c|c|l|c|c|}
\hline Country & $\begin{array}{c}\text { \% high-quality } \\
\text { leadership }\end{array}$ & $\begin{array}{c}\text { \% strong fu- } \\
\text { ture bench }\end{array}$ & \multicolumn{1}{|c|}{ Industry } & $\begin{array}{c}\text { \% high-quality } \\
\text { leadership }\end{array}$ & $\begin{array}{c}\text { \% strong fu- } \\
\text { ture bench }\end{array}$ \\
\hline ASEAN & 42 & 22 & Automotive & 44 & 21 \\
\hline China & 41 & 6 & Education & 45 & 19 \\
\hline Europe & 38 & 13 & Energy/Utilities & 54 & 22 \\
\hline India & 21 & 18 & Banking & 42 & 5 \\
\hline CIS & 20 & 29 & Manufacturing & 35 & 5 \\
\hline USA & 55 & 14 & Technology & 41 & 12 \\
\hline
\end{tabular}

Source: EY, DDI.

Concerning the evaluation of the situation within regions, we see that the USA has preceded Asian countries (on the second position). It is a consequence of rapid development of this region, then - Europe. The CIS, unfortunately, is less preferable also by rating, even lower than India.

On the figure below there are analysis results referring to the impact of identified objectives concerning the achievement of leadership positions at the market of educational services on financial aspects of the organizations of this sector. As we can see on the figure the profitability of the organizations, which do not determine leadership objectives by $42 \%$ lower and vice versa. 


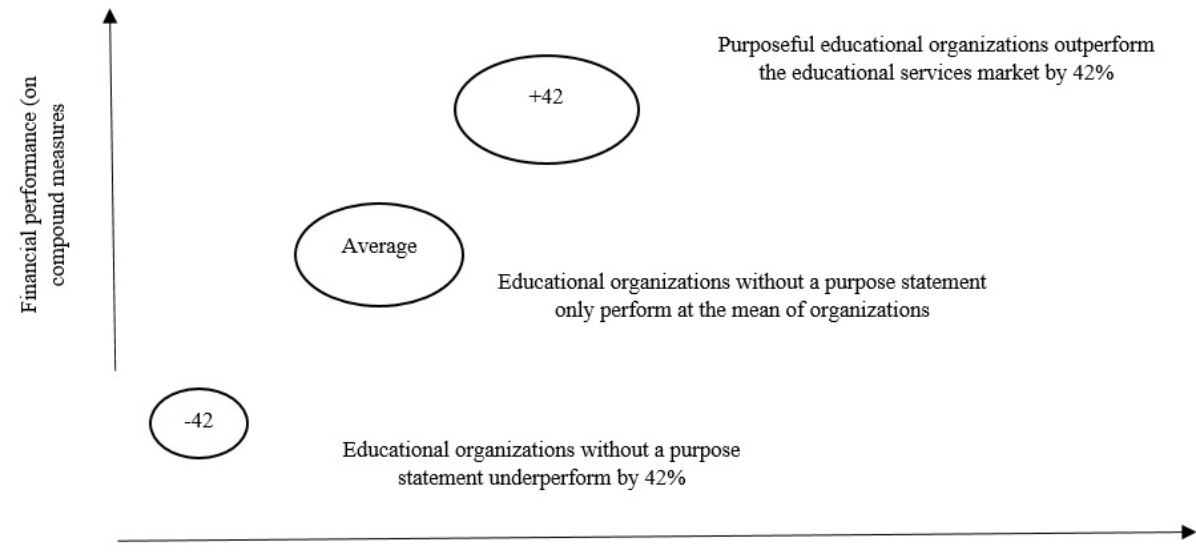

Fig. 2. Influence of objectives' identification as regards concerning the achievement of leadership positions on the market on financial performance of the educational organizations

(Source: developed by authors based on EY, DDI).

OECD experts have assessed the development level of the public services in Russia, Ukraine and Kazakhstan. For the evaluation, models of the public service have been used (Table 2) - professional, strategic and innovative public services [8,24,28]. To estimate the development of the public service, the OECD has applied a conceptual system based on 3 main stages of development: professional, strategic and innovative. These stages are mutually exclusive. Each next stage is taken place based on results of the previous one. A professional public service is characterized by meritocracy and the ability to effectively take advantage of various talents, qualified and ethical employees, as well as leaders who are effective in everyday processes. A strategic public service is differed by its efficiency and attractiveness for top professionals, proactive employees, result-oriented managers who are transformational leaders and know how to manage changes. The key features of an innovative public service are the presence of mobility, diversity and openness, which encourage cultural cooperation, curious employees, as well as adaptive leaders who can collaborate (Table 2).

In case of applying the model for evaluation of public services in the field of education, then as of now we deem that:

- Public service of the European countries may be considered as strategic one with innovative context;

- Public service if the CIS countries are, respectively, a professional one with strategic context.

It is necessary to think about the implementation of worldwide development trends of public services in education to more contemporary ones; the latter can enable to transform the national state authority to a new, strategically innovative level. The final goal of the process is the creation of an attractive public authority for more decent employees of the public service that will become a strategic partner of the society and establish adequate values. 
Therefore, it should not disregard the fact that in developed countries, more and more attention is drawn to the shortage of leaders in the public service and it becomes more and more important to ensure their appearance.

For the majority of the developed countries in the world it is obvious the awareness of modern leadership in the public service as a combination of such qualities and skills as the ability to trace the global situation, establish right goals, inspire and motivate, delegate, create trust-based relationships, etc. We can state that the strongest leadership is an essential factor in creating an innovative and effective team or organization.

So far, it is usual that the concepts of "manager" and "leader" are still the same in public consciousness and practice, and there is no distinction between the qualities of character, skills and competencies inherent in the manager and leader separately. Thus, the existence of leadership skills in a manager allows realizing the aggregate potential of an organization, taking it to a new level with getting better results. And, vice versa, a manager, who does not possess these traits, often limitate the realization in full of the potential of the subordinated team. In this respect, the leadership defines the level of an overall performance.

Table 2. Main stages of the development of the public service in the educational field based on leadership in accordance with OECD methodology

\begin{tabular}{|c|c|c|c|}
\hline Critreria & $\begin{array}{l}\text { Professional public ser- } \\
\text { vice }\end{array}$ & Strategic public service & $\begin{array}{c}\text { Innovative public ser- } \\
\text { vice }\end{array}$ \\
\hline $\begin{array}{l}\text { Necessary qualities of } \\
\text { employees of public } \\
\text { services and institu- } \\
\text { tions }\end{array}$ & $\begin{array}{l}\text { Professionalism } \\
\text { Independence } \\
\text { Values-oriented } \\
\text { Ethics }\end{array}$ & $\begin{array}{l}\text { Result-oriented } \\
\text { Decision making based on } \\
\text { facts } \\
\text { Future-oriented } \\
\text { Proactivity } \\
\text { Ability to establish profes- } \\
\text { sional relationships }\end{array}$ & $\begin{array}{l}\text { Ability to treat data } \\
\text { Citizens-oriented } \\
\text { Aspiration to new } \\
\text { knowledge } \\
\text { Acquiring best practices } \\
\text { Initiative }\end{array}$ \\
\hline $\begin{array}{l}\text { Features of public ser- } \\
\text { vice }\end{array}$ & $\begin{array}{l}\text { Based on reached achieve- } \\
\text { ments } \\
\text { Soft skills, ethics and tal- } \\
\text { ents' management (with fo- } \\
\text { cus not on previous out- } \\
\text { comes but on future poten- } \\
\text { tial) } \\
\text { Proper correlation between } \\
\text { specialized and subject spe- } \\
\text { cialists }\end{array}$ & $\begin{array}{l}\text { Flexible and fast respon- } \\
\text { sive } \\
\text { Attractive for high-quality } \\
\text { specialists } \\
\text { Capable to planning and ef- } \\
\text { ficiently distribute neces- } \\
\text { sary competences under the } \\
\text { principle "in the right place } \\
\text { at the right time" } \\
\text { Future-oriented and respon- } \\
\text { sive }\end{array}$ & $\begin{array}{l}\text { Based on organizational } \\
\text { culture and management } \\
\text { tools oriented on trans- } \\
\text { parency } \\
\text { Unique } \\
\text { Independent } \\
\text { Mobile } \\
\text { Focused on continuous } \\
\text { training }\end{array}$ \\
\hline Qualities of managers & $\begin{array}{l}\text { High-quality developers of } \\
\text { the policy and efficient } \\
\text { managers }\end{array}$ & $\begin{array}{l}\text { Transformation leaders } \\
\text { who can manage changes }\end{array}$ & $\begin{array}{l}\text { Leaders who aim for co- } \\
\text { operation and managers } \\
\text { who easily adapt to } \\
\text { changes }\end{array}$ \\
\hline
\end{tabular}

*Source: developed by authors based on [24]

The same situation is in educational institutions. Taking into account the proactiveness of the new younger generation and free access to knowledge, information on gadgets, a modern teacher must become a leader who leads others with the purpose to interest and retain the students. 
In the contemporary theory and practice of developed countries, the importance of the so-called transformational leadership is highlighted, when a leader (or teacher) works together with employees (or students) to determine the necessary changes, an appropriate view and strategy as well as implements the changes jointly with subordinates. Such a leader strengthens the motivation, morale and performance of followers. In this model, the leader is a role model.

Closely related to leadership, the international trend is the development of so-called "soft skills" among employees in educational area. This term means the complex of such skills, abilities and character traits, such as emotional intelligence, social intelligence, communication skills, ability to work with people, adaptability and positive attitude [18].

It should be noted that "soft" skills do not depend on the level of professional knowledge and allow a person to work productively in a social environment. In the framework of ongoing technological progress and a dynamically changing business environment, there is a tendency in attracting of employees, including employees of public service and state educational institutions with precisely such skills. The OECD already defines that hiring such specialists within the current labor market is critical. Nowadays various technologies and artificial intellect are already able to perform typical duties of the employee, namely starting from creating template letters and treatment of big data to providing public services. Therefore, we can state that a civil officer of the digital age will differ from a soulless machine by the presence of soft skills.

We also think that for any organization, which seeks to develop, the practice of elaborating leadership development programs for its employees is

Based on the present research we deem that in order to elaborate an effective leadership development program in the organization it should be taken into consideration the key challenges for managers, which are turned out or can appear in a professional activity of a modern leader (Figure 3 ).

On the Figure 3 we can see that among up-to-date key challenges for managers the development of future leaders has resulted in the majority of respondents' feedback.

Leadership needs investment. Thus, today the business makes significant investments into leadership extension, but statistics shows that they are not enough. The satisfaction with the quality of leadership over previous 6 years has changed slightly from $38 \%$ in 2011 to $42 \%$ in 2017 . Such statistics certifies the absence in many companies of an integrated leadership development model, which would be part of the overall business strategy as a whole. This becomes an obstacle to digital reformatting, which requires new views on employee management and changes in the approaches towards the activities of business leaders.

Digital transformations and technologies undoubtedly influence the development of leadership, define and require new competencies. We can sum up that digital technologies eliminate the traditional attitude to work and significantly change the core competencies. According to the Global Leadership Forecast 2018 study for achieving success in the digital age, the leaders should have such competencies as digital competence, adaptability, decision-making, effective talent management, organizing crossfunctional interactions, and have diversified views. 
The generation of millennials is thought to be sufficiently knowledgeable in the field of digital technologies. They should lead the implementation of digital transformations. However, pursuant to opinions of business managers representatives of generation $\mathrm{X}$ feel more confident in solving problems of modern business.

Below, in the Table 3, there are results of adapting of character traits and competencies, which testify the readiness of main representatives of contemporary generation such as baby boomers (oldest generation), millennials and generation Z (young) to key and new challenges in education. Below a rating scale from 1 (the highest degree of readiness for the challenge / or duty) to 9 points (respectively, the lowest degree of readiness) is presented.

Table 3. Readiness of this-generation leaders to key challenges and new duties as an educational employee

\begin{tabular}{|c|c|c|c|c|}
\hline \multirow[t]{2}{*}{$\#$} & \multirow[t]{2}{*}{ Challenge } & \multicolumn{3}{|c|}{ Type of modern generation } \\
\hline & & Baby boomers & Millennials & Generation $Z$ \\
\hline 1. & Understanding social needs and feedback & 1 & 2 & 3 \\
\hline 2. & $\begin{array}{l}\text { Forecasting and being responsive to changes and the } \\
\text { emergence of innovations in legislation }\end{array}$ & 2 & 1 & 1 \\
\hline 3. & $\begin{array}{l}\text { Decision-making based on big data that are to be im- } \\
\text { mediately, on time and adequately treated; }\end{array}$ & 3 & 5 & 7 \\
\hline 4. & $\begin{array}{l}\text { Be result-oriented despite continuous changes and } \\
\text { unsteady environment }\end{array}$ & 4 & 3 & 2 \\
\hline 5. & Team work, commitment & 4 & 6 & 7 \\
\hline 6. & Overcoming difficulties & 5 & 4 & 5 \\
\hline 7. & $\begin{array}{l}\text { Complex and multi-level structure of public educa- } \\
\text { tion management }\end{array}$ & 5 & 6 & 7 \\
\hline 8. & Competition & 6 & 6 & 7 \\
\hline 9. & Work in digital environment & 6 & 7 & 9 \\
\hline 11. & Decision-making & 8 & 7 & 4 \\
\hline 12. & $\begin{array}{l}\text { Transfer and knowledge gathering within the organi- } \\
\text { zation }\end{array}$ & 9 & 8 & 8 \\
\hline
\end{tabular}

Clarified and added for public service activity in the educational sphere [2].

Thus, according to Table 3 younger generation - $\mathrm{Z}$ - is less prone to make decisions independently, to share knowledge (it is partially explained by their age). However, they are more efficient in the digital environment, teamwork, quick and proper analysis of large data and subject to analytical thinking.

However, the millennials, who now take managerial positions, are quite sophisticated in digital technologies. According to statistics, 54\% millennials out of $56 \%$ are skillful in digital technologies and more professional in such key leadership principles as result orientation and talent management.

The latest changes affect the core competencies of leaders and their attitudes towards work. A modern organization must create an effective training culture so that employees could be aware of the necessity of personal development and make efforts to reach it. As a solution, it is necessary to organize the work by forming separate teams to 
achieve a common objective. The employee management system itself must change, be more flexible, integrated, technological.

In general, the abovementioned issues related to the development of "educational" leadership supposed to maintain the existing and form new leadership skills within today period of important changes. Now most potential leaders prefer a personalized learning. However, many companies do not pay due attention to such needs. That is why the investment will be useless and old-fashioned tools have been applied.

In overall, we can state that now instructional methods (lectures, courses, full-time learning in higher education institutions) are old-fashioned, not interesting for young generation.

Now they wish to have more practice, interesting topics, workshops, remote learning, mobility programs abroad, challenges that allow active young people not staying at one place and striving to develop, actively acquire best practice, one after another, alongside with the study of foreign languages and capability to travel.

In order to succeed in effective education, modern organizations have to constantly analyze training needs and intensively elaborate training programs for leaders. As an example, there are companies where Learning Experience Manager works and who builds up personalized training programs. In such companies, there is a highly effective system of forming and improving leadership.

For leadership extension, it is critical to reject from self-study. Based on analysis results the education programs, which attracts teachers and coaches, are considered to be more effective. Moreover, now most companies have actively introduced consulting and training methods as well as attracting mentors to train their leaders. In such companies, there is a substantial employee pool and there is almost no managers' turnover.

To sum up, public units and services are deemed to function by using more effective and modern practices of training leaders in public service and new competencies of the modern leader, which are necessary for his/her development and competitiveness in the labor market. The public units and services are responsible for training, career enhancement and promotion of their employees.

\section{Results}

We should create a comprehensive career enhancement system in public sector. The latter will cover all key cooperation items: recruitment, adaptation, training and development, performance evaluation, leadership development, recognition and remuneration, career management and other operational processes. In fact, future students when choosing the occupation consider areas with career opportunities. HR specialists are liable to create the environment where employees can actively develop and meet current and future requirements of public service. In this regard, it is reasonable to elaborate career maps for key positions with a description of expectations and requirements for an employee at each position as well as to make up special programs for developing future managers (leaders) of the public service. 
One of the main tasks of the manager (leader) is to motivate and inspire employees. The manager (leader) identifies the strengths and aligning the weak ones of each employee. Therefore, in addition to developing professional competencies, an effective leader needs to work on extending the emotional intelligence and other skills for effective interaction with colleagues.

Next topic is emotional intelligence. Based on world-scale data, organizations where managers are leaders with high emotional intelligence increase their profitability and social effects arise (which is necessary for public service). This does not happen in those organizations where managers are not aware of how to manage their emotions and emotions of subordinates.

The abovementioned new objectives of educational institutions related to leadership development for formation of another view on motivation of young generation are of conceptual character. This suggests that in order to create an effective system of employee management in the public service and enhancement of the role of employee services, it is necessary to reform the system of employee work of state bodies. It is important to mention about the necessity to form a new employee service of state bodies as an independent structural unit. Creating an employee service in the central, territorial and regional executive authorities is a critical issue.

Considering the changes and recommendations above on improving the education management, a mechanism for the formation and development of leadership within the state education administration has been developed (Figure 3).

Experts at the World Economic Forum in Davos of this year have defined principles based on which the employee development in a contemporary environment should happen and which have been identified by ONN. They are creativity, critical thinking, cooperation and communication skills, as well as new relevant skills. Most experts in public administration and political leaders have highlighted emotional intelligence as one of the key skills that a public employee needs to acquire for succeeding in his/her profession, be a leader.

Generally, the emotional intelligence is the ability of a person to recognize emotions, to understand the intentions, motivation and desires of other people, as well as their own ones, the ability to control them and the emotions of other people in order to solve current issues.

Emotional leadership is regarded as an art, a tool of employee management based on emotional intelligence.

Emotional leadership in the public education administration in the framework of the study is proposed to be considered as a certain management technology. Based on the skills of public employees as for managing their own emotions, other employees' emotions and society as a whole it allows to reach specified objectives in educational and professional activities, and comply with global government missions.

In most developed countries of the world, established special state educational institutions, apart from professional knowledge, teach the skills that a state and public administrator needs to have. For example, they are the National School of Government, the National Institute for Territorial Studies, the Institute for the Preparation of Deputies of Local Authorities (France), the Federal Academy of Public Administration, the Ba- 
varian School of Management (Germany), the Craiova School of Public Administration, the Higher School of Public Administration (Poland), the Federal Institute of Management (USA), School of Public Service of Canada, etc. In the framework of preparation training cycles of these institutions, not only theoretical forms of training but alternately practice and internship and in-depth practical courses are previewed. The student chooses himself/herself the training forms as well as those that correspond to the specifics of his work. Within the study, we believe that it makes sense to transfer such an experience into the Ukrainian system of training public employees.

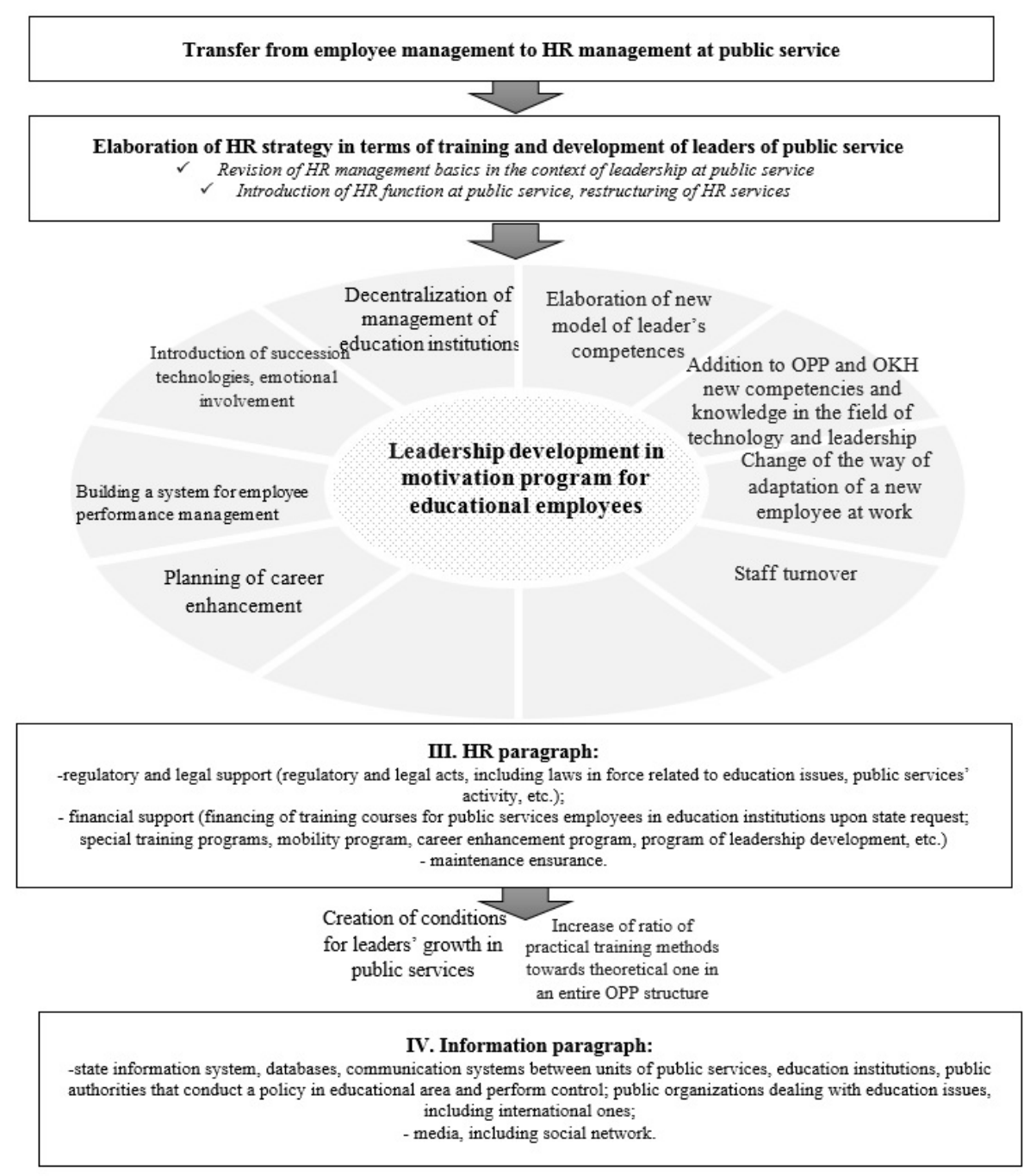

Fig. 3. Mechanism of leadership formation and development within public education management (prepared by author) 
Paper- Motivation and Employee Effectiveness in Online Learning Environments: Leadership ...

There is a relationship between leaders' emotional intelligence and effective performance.

Emotional leadership is developed through development of coaching, mentoring, feedback and communication skills. The manager should be capable to define the strengths of the employees, how to train, motivate, identify the values of the employees, to delegate the responsibility based on the employees' strengths.

Motivation can be considered as a passion for work caused by other reasons rather than money or status, as well as a great wish to achieve goals with energy and perseverance. Outstanding features are a strong motivation for acquiring optimism even in case of failures and organizational commitments.

The model of emotional intelligence by D. Goleman has become a basis for setting up the model above. The scientist-psychologist has proposed the interpretation of the concept "emotional intelligence", which is still relevant today, in 1995. D. Goleman for the first time has identified five main components of the emotional intelligence, namely managing and understanding other people, motivation, control and awareness of oneself.

Moreover, apart from D. Goleman, G. Gardner wrote about the emotional intelligence in his works in 1983. He proposed a model of multiple mental abilities, as well as P. Salovey and J. Meyer - in their works (a comprehensive theory of emotional intelligence) [29].

We pay attention to the fact that for a long time the emotional intelligence was considered primarily within the psychology. It meant a combination of certain manipulative actions that could make a person to fulfill the wishes and duties of a manipulator that has used this method. From the perspective of leadership theory, in particular in public administration, the emotional intelligence is deemed as a certain technology. It helps to achieve common goals, public administration mission, and the emotional intelligence began to be used predominantly over the last decade.

The main areas in which the technology of emotional intelligence can be used are in online learning environments at universities while the preparation of public employees, in the offices for professional development and in everyday life.

The emotional intelligence and emotional leadership, except training processes, have been used so far only in methodologies of employees' performance assessment, both business and public sector of western countries. These methodologies are elaborated based on the theory of social exchange. The theory supposes that employee and employer share their values with each other. They help to estimate and define the emotional state and level of employees' involvement in the activity. In turn, it enables to determine how much the employee is involved in the activity, receives support from his/her supervisor. The supervisor assesses the performance efficiency of the involved employee and his/her contribution in overall; employee's psychological dedication to work, his/her not indifference to the tasks assigned, helps to understand how active the employee is, whether he/she has leadership qualities and skills, and the employee's behavior while performing more complex tasks. 


\section{Discussion}

Current trends in the dynamic development of society require an in-depth usage and enhancement of leadership importance. Leadership is a phenomenon that, without exaggeration, may be specific to the humanity as a society. Moreover, the leadership is suggested to have a biological origin. To reach an effective management on the basis of leadership development is one of the current issues today and many studies have been carried out to solve it $[2,19,30]$.

Also, one's set of skills relative to primary leadership and digital management learning is largely pre-determined by the elementary education. Many researchers have drawn attention to the fact that several subsequent generations of the so-called digital natives have their carriers dependent upon the teaching methods they were exposed to in the elementary school [31-33]. A critical factor seems to be the integration of mobile and e-learning with the earliest development programs, typically used when the child's personality is passively developing.

The peculiarities of the specified issue are its volume and diversity of management situations, subjects and objects of the management process, the non-homogeneity of the ties between them, the impossibility of explicit identification of efficiency criteria in many cases, as well as the high changing factors and their adjustment of the effectiveness of the development improvement. This determines the importance of objective, quantitative assessment of the influence of motivational systems on employees' efficiency, and the organization as a whole $[11,34,35]$.

Due to analysis results, the works by other authors have demonstrated that firstly, almost all of them try to assess in numbers the impact of incentive and motivation on financial performance of organizations, and secondly, the results of the assessment are very inadequate [36-38].

In this study, the authors brought together different methods and systems for assessing the necessary skills and abilities that determine a leader. The understanding of these skill sets is critically necessary to improve the training of leaders with qualities that can be predicted at the final stages of training. Leadership training programs cannot always be adequately assessed, and most studies do not deal specifically with the leadership formation issues. In most cases, they investigate what leads to an adequate manifestation of leadership qualities, e.g., the company's revenues or achievements in the field of public perception [20,34].

The latest studies in the five-year range revealed no layout of principles and methods for the formation of leadership qualities in an e-learning space. Our work partially closes this gap and may become a starting point for numerous studies.

A successfully elaborated system of motivation and encouragement is based on the use of leadership technologies and emotional intelligence, which will allow to identify more precisely the employees who work more efficiently, are able to influence the performance of their subordinates (or students' learning outcomes - for educational institutions). The study should be directed towards the extension of the impact of leadership technologies and emotional intelligence applied in the activity of educational institution on the financial results and formation of organization's goodwill. However, we believe 
Paper-Motivation and Employee Effectiveness in Online Learning Environments: Leadership ...

that it is necessary to think about the approach that enables to obtain a more accurate assessment than in the reviewed works above.

\section{Conclusion}

The research, stipulated in the work, has covered issues related to the formation of a modern, effective system of motivation and encouragement; that is required to revise the operational concepts of both educational institutions and public authorities related to education management in the country. Today, the public service within education management is faced with a challenge to transform the organization into a highly efficient, flexible, citizen-oriented and constantly improving one. The main assets of the organization are its employees. Their high professionalism and effectiveness are evidence of their dedication and productive contribution into well-being of the citizens of the country. In order for highly professional employees to succeed in the educational sphere on the long-term basis, the latter should become an attractive place of employment from all perspectives.

It is necessary to make maximum efforts for improving the image, presentation skills, role of the employee of the educational organization as well as for improving the level of working in online environments. For attraction of highly potential graduates of institutions of secondary education, future leaders should wish to choose this occupation. Therefore, an image change of the representative of the specified occupation will cause a high efficiency in adhering to the society needs and the attractiveness of a career in education, science and public service (education management).

Moreover, the introduction of meritocracy principles, competence-based approach, further improvement of the remuneration system of employees in the educational sphere, development of the institute of senior state employees managing education in the country are evident needs as well as consistency with international best practices.

Online technologies, leadership strategies and emotional intelligence are relevant today and are universal in nature. They are used in the management of both educational processes and educational institutions in many countries around the world, which stipulates a wide range of research outcomes described in the work as in international and as in national education management practices.

The study can find practical application when redefining training programs for public and corporate managers, identifying performance markers, and when choosing training programs for leaders. The present findings will be effective if applied to educational employee training programs.

Further research in this field may involve exploring the effectiveness and quality of various training programs designed for educational employees, investigating various aspects associated with the use of approved online services and technologies to enhance learning and self-efficacy of teachers who use mobile and e-learning technologies. 


\section{References}

[1] Frost, D. (2014). Leadership for Learning. The Cambridge Network. Available online: www.educ.cam.ac.uk/centres/lf (accessed on 10 October 2019).

[2] Global Leadership Forecast (2018). "Development Dimensions International". Inc. The conference board Inc., EYGM Limited. Available online: https://www.ddiworld.com/DDI/media/trend-research/glf2018/global-leadership-forecast2018 ddi tr.pdf? ext=.pdf (accessed on 10 October 2019).

[3] PISA (2018). Capacity needs analysis: Ukraine. Available online: https://www.oecd.org/pisa/aboutpisa/Ukraine-PISA-capacity-needs-analysis.pdf (accessed on 10 October 2019).

[4] Pletyago T.Y., Ostapenko A.S., Antonova S.N. (2019). Pedagogical models of blended learning: On the experience of Russian and foreign practice of design and implementation. The Education and science journal, 21(5):112-129. (In Russian). https://doi.org/10.17853/ 1994-5639-2019-5-113-130

[5] Ferreira, A., Du Plessis, T. (2009). Effect of online social networking on employee productivity. South African Journal of Information Management, 11(1): 1-11. https://doi.org/10.10 16/i.chb.2010.01.011

[6] Chen, K. C., Jang, S. J. (2010). Motivation in online learning: Testing a model of self-determination theory. Computers in Human Behavior, 26(4): 741-752.

[7] Buttner, E.H., Lowe, K.B. (2017). The relationship between perceived pay equity, productivity, and organizational commitment for US professionals of color. Equality, Diversity and Inclusion: An International Journal, 36(1): 73-89. https://doi.org/10.1108/edi-02-2016-0016

[8] Performance Management, 2019. Available online: https://www.ddiworld.com/glf2018/performance-management (accessed on 10 October 2019).

[9] Marcus, V. B., Atan, N. A., Talib, R., Latif, A. A., Yusof, S. M. (2019). Promoting Students' Generic Skills with the Integration of e-Service Learning Platform. International Journal of Emerging Technologies in Learning (iJET), 14(20): 4-17. https://doi.org/10.3991/ijet.v14 $\underline{\mathrm{i} 20.11455}$

[10] Kouzes, J.M., Posner, B.Z. (2010). The truth about leadership: The no-fads, heart-of-thematter facts you need to know. San Francisco, CA: Jossey \& Bass.

[11] Klenke. K. (2011). Leadership: Contextual boundaries and dynamics. UK: Emerald Publishing Group Limited.

[12] Liao, C. W., Chen, C. H., Shih, S. J. (2019). The interactivity of video and collaboration for learning achievement, intrinsic motivation, cognitive load, and behavior patterns in a digital game-based learning environment. Computers \& Education, 133: 43-55. https://doi.org/10. $\underline{1016 / j . c o m p e d u .2019 .01 .013}$

[13] Blondel, J. (1987). Political leadership: Towards a general analysis. London; Beverly Hills: SAG.

[14] Riaz, S., Rambli, D. R., Salleh, R., Mushtaq, A. (2010). Study to investigate learning motivation factors within formal and informal learning environments and their influence upon web-based learning. International Journal of Emerging Technologies in Learning (iJET), 5(4): 41-50. https://doi.org/10.3991/ijet.v5i4.1338

[15] Panigrahi, R., Srivastava, P. R., Sharma, D. (2018). Online learning: Adoption, continuance, and learning outcome-A review of literature. International Journal of Information Management, 43: 1-14. https://doi.org/10.1016/j.ijinfomgt.2018.05.005

[16] Lencioni, P. (2012). The Five Dysfunctions of a Team: Intact Teams Participant Workbook. Available online: http://www.ozon.ru/context/detail/id/17128460/ (accessed on 10 October 2019). 
Paper- Motivation and Employee Effectiveness in Online Learning Environments: Leadership ...

[17] Raina, R., Roebuck, D.B. (2016). Exploring cultural influence on managerial communication in relationship to job satisfaction, organizational commitment, and the employees' propensity to leave in the insurance sector of India. International Journal of Business Communication, 53(1): 97-130. https://doi.org/10.1177/2329488414525453

[18] New traditions in public Administration, 2017. Available online: https://www.crcpress.com/rsc/downloads/New Traditions in Public_Administration FreeBook.pdf (accessed on 10 October 2019).

[19] Hanaysha, J.R, Majid, M. (2018). Employee motivation and its role in improving the productivity and organizational commitment at higher education institutions. Journal of Entrepreneurship and Business, 6(1):17-28. https://doi.org/10.17687/jeb.0601.02

[20] Human Resources (2019). Compensation \& Benefits. Prospective Full-Time Employee. PACE UNIVERSITY. Available online: https:/www.pace.edu/human-resources/compensation-benefits/prospective-full-time-employee (accessed on 10 October 2019).

[21] Shatunov, S. (2011). Myth about 20 years of Russian Educational Reforms. Available online: http://www.gzt.ru/print/352166.html (accessed on 10 October 2019).

[22] Tsyrlina-Spady, T. (2016). Modern Russian Reforms in Education: Challenges for the Future. Seattle Pacific University. Available online: https://jsis.washington.edu/ellisoncenter/wp-content/uploads/sites/13/2016/08/pdf-tsyrlina-spady.pdf (accessed on 10 October 2019). https://doi.org/10.18411/d-2016-154

[23] Kaldybaev, S. (2018). Reform Analysis in Higher Education System of the Kyrgyz Republic. 21st Century Pedagogy, 1(1): 16-19. https://doi.org/10.2478/ped21-2018-0003

[24] OECD (2017). OECD Reviews of Integrity in Education: CIS. Available online: http://www.oecd.org/publications/oecd-reviews-of-integrity-in-education-ukraine-9789264 270664-en.htm (accessed on 10 October 2019). https://doi.org/10.1787/9789264270664-en

[25] Salary and Benefits (2019). Available online: http://www.calhr.ca.gov/employees/pages/salary-and-benefits.aspx (accessed on 10 October 2019).

[26] Employment Benefits (2019). Available online: https://content.statefundca.com/careers/CompensationAndBenefits.asp (accessed on 10 October 2019).

[27] Compensation \& Benefits (2019). Available online: https://www.sdbor.edu/administrativeoffices/human-resources/Pages/CompensationBenefits.aspx (accessed on 10 October 2019).

[28] Eurostat (2019). Available online: https://ec.europa.eu/eurostat (accessed on 10 October 2019).

[29] Goleman, D., Boyatzis, R.E., McKee, A. (2013). Primal Leadership: Unleashing the Power of Emotional Intelligence. Harvard Business Press, Business \& Economics. https://doi.org/10.1108/jocm.2003.16.1.123.3

[30] Mohr, G., Wolfram, H. (2008). Leadership and effective: The role of leaders' verbal behavior. British Journal of Management, 19: 4-16.

[31] Papadakis, S. (2018). Evaluating pre-service teachers' acceptance of mobile devices with regards to their age and gender: a case study in Greece. International Journal of Mobile Learning and Organisation, 12(4): 336-352. https://doi.org/10.1504/ijmlo.2018.10013372

[32] Papadakis S., \& Orfanakis V. (2017). The Combined Use of Lego Mindstorms NXT and App Inventor for Teaching Novice Programmers. In: Alimisis D., Moro M., Menegatti E. (Eds.), Educational Robotics in the Makers Era. Edurobotics 2016. Advances in Intelligent Systems and Computing, vol 560, pp.193-204. Springer, Cham. https://doi.org/10.1007/9783-319-55553-9 15

[33] Kalogiannakis, M., Papadakis, S. (2019). Evaluating pre-service kindergarten teachers' intention to adopt and use tablets into teaching practice for natural sciences. International Journal of Mobile Learning and Organisation, 13(1): 113-127. https://doi.org/10.1504/ ijmlo.2019.10016617 
Paper- Motivation and Employee Effectiveness in Online Learning Environments: Leadership ...

[34] Atmojo, M. (2015). The influence of transformational leadership on job satisfaction, organizational commitment, and employee performance. International research journal of business studies, 5(2): 113-128.

[35] LeDoux, J. (2017). Financial Acumen Competency Model for Healthcare Leader. Available online: https://www.td.org/insights/a-financial-acumen-competency-model-for-healthcareleaders (accessed on 10 October 2019).

[36] Purvanova, R.K., Bono, J.E. (2009). Transformational leadership in context: Face to face and virtual teams. The Leadership Quarterly, 20(3): 343-357. https://doi.org/10.1016/j.leaqua.2009.03.004

[37] Sohail, R.S., Saleem, S., Ansar, S., Azeem, A. (2014). Effect of work motivation and organizational commitment on job satisfaction: (A Case of education industry in Pakistan). Global Journal of Management and Business Research, 14(6): 41-46.

[38] Cropf, R.A., Wagner, J.L. (2017). American public administration: public service for the twenty-first century. Routledge. https://doi.org/10.4324/9781315271200-1

\section{Authors}

Nail Israfilov is a Doctor of Economic Sciences, Professor of the Department of Management and Marketing in University associated with Inter-Parliamentary Assembly of Eurasian Economic Community, St. Petersburg, Russia.

Oksana Borisova - lecturer, Department of language training, Financial University under the Government of the Russian Federation, Moscow, Russia.

Oxana Kartashova is a Candidate of Pharmaceutical Sciences, Docent of the Department of Organizations and Economics of Pharmacy, Sechenov First Moscow State Medical University (Sechenov University), Moscow, Russia.

Nataliia Davydova - Candidate of Technical Sciences, Associate Professor, Russian State Vocational Pedagogical University, Yekaterinburg, Russia.

Galia Biserova is a Candidate of Pedagogic Sciences, Associate Professor, Department of Psychology, Elabuga Institute (branch) of Kazan (Volga Region) Federal University, Elabuga, Russia.

Aleksandr Gryaznukhin - PhD in history, Associate Professor, Department of Russian History, Siberian Federal University, Krasnoyarsk, Russia.

Article submitted 2020-02-25. Resubmitted 2020-03-29. Final acceptance 2020-03-30. Final version published as submitted by the authors. 